\title{
THE INFLUENCE OF PERCEIVED EASE OF USE AND USEFULNESS OF THE ACADEMIC REGISTRATION SYSTEM ON THE ATTITUDE OF USING ONLINE STUDY PLAN CARD (KRS)
}

\author{
Tri Rahmat \\ Sekolah Tinggi llmu Ekonomi Panca Bhakti Palu \\ E-mail: trirahmat@stiepbpalu.ac.id
}

\begin{abstract}
This research investigated the factors affecting the academic registration system used by students in STIE Panca Bhakti Palu based on the Theory of Technology Acceptance Model (TAM). Research data were collected through the survey. Out of 294 questionnaires distributed to the respondents, 269 questionnaires were returned back (92\%), while 25 questionnaires (8\%) were incompletely filled in. The obtained data underwent the Structural Equation Model (SEM) analysis using Amos 20 for Windows software. The results of this research showed that the ease of use and usefulness had a positive and significant influence on users' attitude in using the system. Meanwhile, the ease of use positively and significantly influenced the usefulness of the system.
\end{abstract}

Keywords: online KRS, technology acceptance model, perceived ease of use, perceived usefulness and attitude

JEL Classification: L15, L86, M15

\begin{abstract}
ABSTRAK
Penelitian ini menyelidiki faktor-faktor yang mempengaruhi sistem pendaftaran akademik yang digunakan oleh siswa di STIE Panca Bhakti Palu berdasarkan Theory of Technology Acceptance Model (TAM). Data penelitian dikumpulkan melalui survei. Dari 294 kuesioner yang dibagikan kepada responden, 269 kuesioner dikembalikan (92\%), sementara 25 kuesioner (8\%) tidak diisi. Data yang diperoleh menjalani analisis Structural Equation Model (SEM) menggunakan Amos 20 untuk perangkat lunak Windows. Hasil penelitian ini menunjukkan bahwa kemudahan penggunaan dan kegunaan memiliki pengaruh positif dan signficaint pada sikap pengguna dalam menggunakan sistem. Sementara itu, kemudahan penggunaan berpengaruh positif dan signifikan terhadap kegunaan sistem.
\end{abstract}

Kata kunci: KRS online, model penerimaan teknologi, persepsi kemudahan penggunaan, persepsi manfaat dan sikap

Klasifikasi JEL: L15, L86, M 15 


\section{Tri Rahmat}

\section{INTRODUCTION}

Management of higher education cannot be separated from the utilization of information technology development. Through the use of information systems, handling problems, such as administration of new student admissions, data management and students' academic information, the implementation of lecture activities, resource management, and the process of executive policy making, can be completed effectively and efficiently.

The advancement of information technology facilitatesalmost all organizational activities in the forms of applications and automation. Information technology is defiend by Sutabri (2014: 3) as a way to process data, including processing, obtaining, compiling, storing, manipulating data in various ways to produce quality information that is relevant, accurate and precise used for personal, business, and government purposes and decision making.

Meanwhile, Kadir and Triwahyuni (2013: 10) defined Information technology as the study of the use of electronic equipment, especially computers, to store, analyze, and distribute any information, including words, numbers and images. More specifically, information technology is defined by Darmawan (2012: 17) as the results of human engineering on the process of delivering information from sender to the recipient that is faster, wider coverage and longer storage.

Based on the above definitions, The action needing to be taken by educational institutions to improve these services is by optimizing the ability of human resources as well as to improve infrastructure supporting the continuity of educational services in accordance with the development of Science and Technology (IPTEK) which is a source of information can increasing one's knowledge or insight in the field of technology and bring people more advanced and modern.

In line with the above description, College of Economics (STIE) Panca Bhakti Palu has implemented a website-based online Study Plan Card (KRS) information system in academic activities. In some cases, the use of the system has not been felt to be optimal although the system has been implemented. There are several factors determining the level of utilization of this system, such as information content, ease of access, and availability of systems that are often not in accordance with the wishes of its users.

The evaluation process is considered to be very important for the performance of the study plan card information system, how well the system meets its objectives or to improve the sustainability of the service. Because of the importance of a service to an organization, in this 
case STIE Panca Bhakti Palu, it is necessary to make efforts to find out what factors affect the user's acceptance toward the academic registration of the online Study Plan Card (KRS).

In the implementation of technology, Jogiyanto (2008) stated that obstacles are not caused by only technical aspects, but also user behaviour. Low level of user acceptance inhibit the success of technology-based information systems implementation (Davis, 1993).

One of user acceptance models of appropriate technology to date is the Technology Acceptance Model (TAM) proposed by Davis et al. (1989) in Portner and Donthu (2006) mentioned that that TAM shows the perception of ease of use and usefulness are a belief in the existence of new technology that affects the user's attitude towards the new technology that influences the user's attitude. In accepting a new information technology-based system, some people might not be able to understand and accept it. Therefore it is necessary to measure the level of user acceptance and understanding by measuring users' behaviour. In relation to behavioral information system, there are several theories that can be used to study and measure user behavior in receiving information systems, one of which is the Technology Acceptance Model (Jogiyanto, 2008: 14).

Davis et al. (1989) defined TAM as a model designed to predict the acceptance of information technology among. TAM allows researchers to predict the factors influencing the acceptance of a technology among users. Individual acceptance of information technology can be determined by 2 main constructs in TAM that are the perceived ease of use and perceived usefulness (Jogiyanto, 2008: 111-112). According to (Jogiyanto, 2008: 134) some advantages of the Technology Acceptance Model theory include:

1. TAM is a behavioural model that answers questions on why many information technology systems failed to be implemented due to users' resistance in using them.

2. TAM was developed based on strong theoretical basis.

3. TAM has been validated by most researchers, stating TAM is an appropriate model. Conceptually, TAM (Davis et al., 1989) has two main constructs including perceived usefulness and perceived ease of use. When the service provides benefits and ease of use, users will be likely to accept the system since the service will make it easier for users to complete their tasks and improve performance (Jogiyanto, 2008: 114-115).

This research analyzed the factors that influence the users' acceptance upon Online KRS in Panca Bhakti College of Economics (STIE) Palu based on the Technology Acceptance Model (TAM) approach. This research provides excellent service to users in STIE Panca Bhakti Palu students and provides a reference for other universities regarding the implementation of information technology-based management. Similarly, Sutarman (2009) stated that 


\section{Tri Rahmat}

information technology functions to solve problems, improve creativity and increase effectiveness and efficiency in doing work or tasks. The purpose of this research is to determine users' acceptance upon Online KRS as a service system that has an impact on improving the quality of service, instead of merely an obligation for registration.

\section{LITERATURE REVIEW}

\section{Technology Acceptance Model}

Technology Acceptance Model (TAM) is a model of information technology acceptance that was first introduced by Davis et al. (1986) and was developed based on the Theory of Reasoned Action (TRA) by Ajzen and Feishbein (1980). This Technology Acceptance Model (TAM) is one of the most frequently used theories in measuring the level of user acceptance and understanding in using a new service (Jogiyanto, 2008: 114-115). TAM model was actually adopted from the TRA model in the form of a theory of reasoned action assuming that one's perception and reaction to something can be used to determine one's attitude and behavior. Users' perception and reaction will be able to influence one's attitude in accepting information technology (Adhiputra, 2015).

In the Technology Acceptance Model (TAM), there are 2 main constructs that can affect each user's behavior, namely perceived ease of use and perceived usefulness. Of the two variables can explain the aspects regarding user behavior. Hence, the ease of use and benefits ones' obtained from using certain information technology product can be used as a reason for someone to behave or act as a benchmark in accepting an information technology system. Easier use of information technology indicates that less effort is needed to improve one's performance using information technology. The greater the benefits perceived by users, the greater the influence in using information technology. (Jogiyanto, 2008: 111).

The Technology Acceptance Model (TAM) was developed from a psychological theory explaining that the behavior of information technology-based service users is affected by their belief, attitude, intention, and user behavior relationships (Hendra and Iskandar, 2016). This model is used to explain and estimate user acceptance and the main factors influencing user's behavior in accepting an information technology (Istiarni and Hadiprajitno, 2014). TAM model shows that ones' perception will determine their attitude in using information technology. This model clearly illustrates that the acceptance of certain information technology is influenced by perceived ease of use and perceived usefulness (Adhiputra, 2015).

The literature review regarding to the variables used in this study in the Theory of Acceptance Model (TAM) is as follows: 


\section{Variable of Ease of Use}

Perceived ease of use is a belief about the decision making process in using information technology. Someone's perception of the ease of using information technology shows the extent to which the person believes that using a technology can facilitate the completion of his/her work/tasks. This perception will then affect user's behavior (Adhiputra, 2015). According Jogiyanto (2008: 115), perceived ease of use is the extent to which someone believes that using information technology require them less effort. According to Rahadi and Zainal (2015: 840), individual's level of confidence refers to the believe that an information technology is not difficult to use, easy to understand and does not require special skill to operate. Jogiyanto (2008: 152) said that perceived ease of use can be measured through some indicators including: easy to learn, easy to control, easy to understand, flexible, easy to apply and easy to use. Meanwhile, according to Rahadi and Zainal (2015: 840), perceived ease of use can be measured based on how the system is capable of supporting operations, providing actual information, reducing error rates, easyto operate and whether or not the system requires other additional equipment support.

Perceived ease of use is one of the factors that has been tested in a research conducted by Davis et al. (1989) which results show that this aspect can explain ones' reasons in using certain information system. The research also found that the new system developed is accepted by users. Davis et al. (1989) defined perceived ease of use as the level of one's confidence that byusing a particular system, it can require them less effort. Despite the differences in individual's preference, generally, to avoid rejection from users, a system must be easy to operate without requiring burdensome effort. Perceived ease of use by Davis et al. (1989)in Budi Santoso (2010) The above concept illustrates the benefits of the system to the users associated with easy to learn, controllable, clear and easy to understand, flexible, easy to become skilful and easy to use.

\section{Variable of Usefulness/Benefits}

Shun Wang et al (2003: 501-519) in (Adhiputra, 2015) said that perceived usefulness is a person's sense of trust by using an information technology system in improving their performance. Meanwhile, according to Yasa et al. (2014), perceived usefulness is seen as a person's belief that the use of an information technology will benefit its users. Trust is an important aspect in a decision making process. If someone believes that the use of the Online KRS Information System is useful, the person will likely to use the system. On the other hand, if users believe that the system is less useful, they will not use it (Jogiyanto, 2008: 114).

Jogiyanto (2008: 152) mentioned perceived usefulness can be measured by these following indicators: faster work, higher productivity, better effectiveness, easier work and useful. According to Rahadi and Zainal (2015), perceived usefulness can be measured through 


\section{Tri Rahmat}

some indicators including: ability to provide fast, timely, reliable, low-cost services with proper security and accurate information.

Davis et al. (1989) found that perceived usefulness had a stronger and more consistent relationship with the acceptance of information technology than other variables, such as attitudes, satisfaction, and other perceived measurement. The results of a research conducted by Igbaria (1990) showed similar finding, in which the relationship between perceived usefulness and the use of information systems was found positive. Adams et al. (1992) reviewed two research results replicating Davis et al. (1989) showed that perceived usefulness is the main determinants of the acceptance, while another indicated that both perceived usefulness and perceived ease of use are important factors that influence one's acceptance upon a new system.

In accordance with TAM, the perceived usefulness is also affected by the perceived ease of use because the easier a system is used, the more useful the system is felt. A sense of ease of information technology system usage will cause a feeling in someone describing that the system has usefulness, and therefore, it creates a sense of comfort when working with information technology systems (Davis et al., 2000). From various empirical tests on TAM, the perceived usefulness consistently is a factor determining the user's willingness to use the system. Perceived usefulness according to Davis et al. (1989) in Budi Santoso (2010) The concept above illustrates the benefits of the system for the user associated with work faster, work performance, increase productivity, effectiveness, make work easier and useful.

\section{Variable of Usage Attitudes}

Davis in Jogiyanto (2008: 117) explained TAM conceptualizes attitude towards the use of a system in the form of acceptance or rejection as an outcome of a person using certain information technology at work. The attitude in the forms of acceptance or rejection is determined by the level of trust. A person with high level of trust in an information technology will show a positive attitude in the form of acceptance.

According to Setiadi (2003: 213), users' attitude is reflected by one's belief and preference upon services. Attitudes towards certain brands or services will affect one's behavior. Attitudes also affect one's reaction whether or not to use certain service.

Gordon Allport in Setiadi (2003: 214) defined attitude as the learning about the tendency to give a response either likes or dislikes. Whereas according to (Rangkuti, 2013: 62), attitude is as an emotional feeling, evaluation and tendency of actions that are beneficial or unfavorable against an object or service. Thus, one's attitude reflect his/her acceptance of 
an information technology. Attitudes can affect user behavior. Users who have positive attitudes towards a service will tend to use the service, and the vice versa. Therefore, it is necessary for information-technology developers to build positive attitude among users (Rangkuti, 2013: 68).

According Jogiyanto (2008: 113), user attitudes show the extent to which theyperceive the system good or bad. If users perceive the information technology-based service is good, then it is possible that they will have positive attitudes and will likely to use the service. On the other hand, when users perceivean information technology-based service bad, they tend to show negative attitude and grow reluctance to use the service. According to Kusuma and Susilowati (2007: 125-139) and Yahyapour (2008: 136) in Adhiputra (2015), attitudes can be measured using some indicators; fun to use, good to use, wise to use, and the necessity to use the system. Meanwhile, according to Rahadi and Zainal (2015: 841) one's attitudes can be indicated by the feelings of like or dislike.

Attitudes toward behaviour according to Fishbein and Ajzen (1975) in Jogiyanto (2008) are defined as the amount of affection (feeling) felt by someone to accept or reject an object or behaviour and are measured by a procedure placing the individuals on a two-pole evaluation scale, which is good or bad, agree or disagree, and others.

\section{METHODS}

The conceptual framework model of this study consisted of perceived ease of use (PEOU) variables, perceived usefulness or benefit (PU) variables, and usage attitude (ATT) variables. The conceptual framework of the study can be seen in Figure 1 as follows:

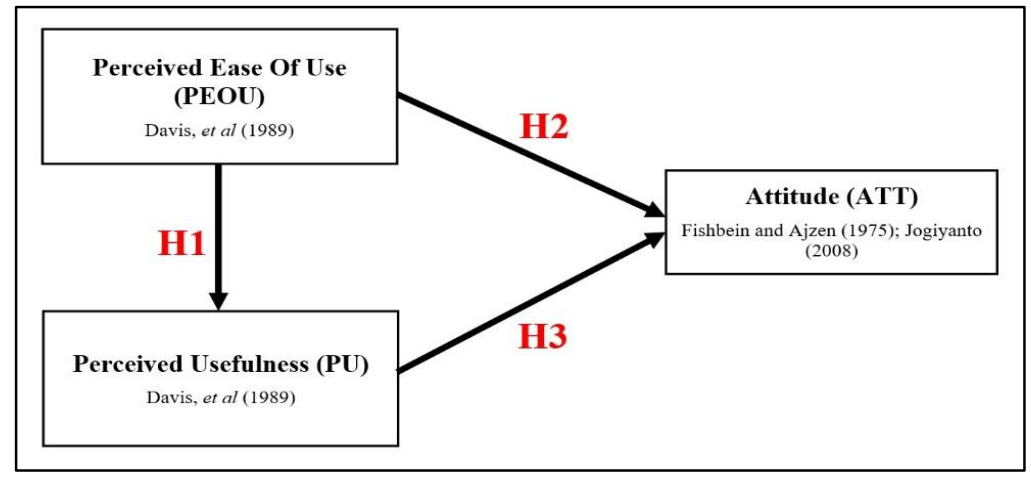

Figure 1.

\section{Research Conceptual Framework}

In this study, the writer used a quantitative method using a descriptive and verification research approach. It was since there are the variables to be examined in their relationship and its aim to present a structured, factual, and accurate description of the facts and the relationship among the variables studied. According to Juliansyah Noor (2011), descriptive 


\section{Tri Rahmat}

method is a study trying to describe a phenomenon, event, current happening case. Descriptive research focuses on the actual problem as it was when the research took place.

According to Mohammad Nazir (2011), the definition of verification method is a research method aiming at determining the causality relationship (cause and effect relationship) among variables through a hypothesis test using a statistical calculation so that the proof of the results shows that the hypothesis is rejected or accepted. The number of samples used in this study was adjusted to the analytical method used which is the Structural Equation Model (SEM). The sample collection technique that will be carried out in this study is non probability sampling with judgmental (purposive) technique. According to Sugiyono (2016) purposive sampling is sample determination using certain considerations. The sample size used in this study is based on the equation formulated by Slovin with references (Principles and Methods of Research), in addition, because of the population number (N), it is known with certainty, then to determine the sample size ( $n$ ) as follows:

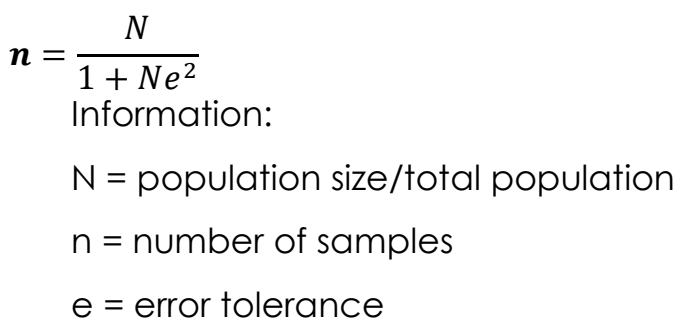

Based on the above formula of Slovin, it is known that $N=1,108$, and $e=5 \%$ so that it can be calculated as follows: $\mathrm{n}=\mathrm{N} /\left(1+\mathrm{N} \mathrm{e}^{2}\right)=1,108 /\left(1+1,108 \times 0.05^{2}\right)=293.901294$.

Table 1.

Calculation on the Number of Sub-Population Samples

\begin{tabular}{|c|c|c|c|c|}
\hline Study Program & $\begin{array}{c}\text { Total } \\
\text { Population }\end{array}$ & & Calculation & $\begin{array}{l}\text { Number of } \\
\text { Samples }\end{array}$ \\
\hline Accounting & 1.108 & $\begin{array}{c}504 \\
1.108\end{array}$ & $\begin{array}{l}\times 100 \%=45,5 \% \times 294= \\
133,77\end{array}$ & 134 \\
\hline Management & 1.108 & $\begin{array}{c}604 \\
1.108\end{array}$ & $\begin{array}{l}\times 100 \%=54,5 \% \times 294= \\
160,23\end{array}$ & 160 \\
\hline Total Samples & & & & 294 \\
\hline
\end{tabular}

Source: PDPT STIE Panca Bhakti Palu

From the calculation of the above formula of Slovin, it is known that the number of samples used in the study was 294 respondents from the academic year of 2015 to 2018 in which the study program of accounting is 134 respondents, and the study program of management is 160 respondents. Respondents are a student who has active status in Academic Year of $2018 / 2019$.The distribution of questionnaires to 294 research respondents is described in Table 2. 
Table 2.

The Distribution of Questionnaires

\begin{tabular}{clll}
\hline No. & Questionnaire Distribution & Frequency & Percentage \\
\hline 1 & Returned questionnaires/completed & 269 & $92 \%$ \\
2 & Invalid questionnaires & 25 & $8 \%$ \\
Total & & $\mathbf{2 9 4}$ & $\mathbf{1 0 0 \%}$ \\
\hline
\end{tabular}

Source: Processed Primary Data

As described in Table 2, out of 294 questionnaires distributed to the research samples, 269 questionnaires were returned back $(92 \%)$, while 25 questionnaires were regarded invalid or incomplete (8\%). Detailed information about the number of samples in each enrolment year is presented in Table 3.

Table3.

Respondents' Data Based on Enrolment Year

\begin{tabular}{cccccc}
\hline No. & $\begin{array}{c}\text { Enrolment } \\
\text { Year }\end{array}$ & Accounting & Management & Frequency & Percentage \\
\hline 1 & 2015 & 21 & 24 & 45 & $16.73 \%$ \\
2 & 2016 & 42 & 34 & 76 & $28.25 \%$ \\
3 & 2017 & 23 & 36 & 59 & $21.93 \%$ \\
4 & 2018 & 30 & 59 & 89 & $33.09 \%$ \\
& Total & $\mathbf{1 1 6}$ & $\mathbf{1 5 3}$ & $\mathbf{2 6 9}$ & $\mathbf{1 0 0 . 0 0 \%}$ \\
\hline
\end{tabular}

Source : Processed Data, 2019

Table 3 shows there are 45 respondents from the class of 2015 (16.73\%), 76 respondents from the class of 2016 (28.25\%), 59 respondents from the class of 2017 (21.93\%) and 89 respondents from the class of 2018 (33.09\%). The data analysis technique is carried out by looking at the assumption of Structural Equation Modelling (SEM) as well as the suitability test and statistical tests which are all done with SPSS 20.0 and AMOS 20.0 for windows.

\section{RESULTS AND DISCUSSION}

\section{Drafting Flowcharts}

Based on a theoretical review, a flowchart of causality relationships between constructs and their indicators can be made. This relationship can be seen in Figure 2. In drafting the flowchart, as explained in the operational definition, it consists of 3 constructs and 11 indicators. In Figure 2, the following is a figure of the flowchart model of causality relationships with Amos 20.0 for windows: 


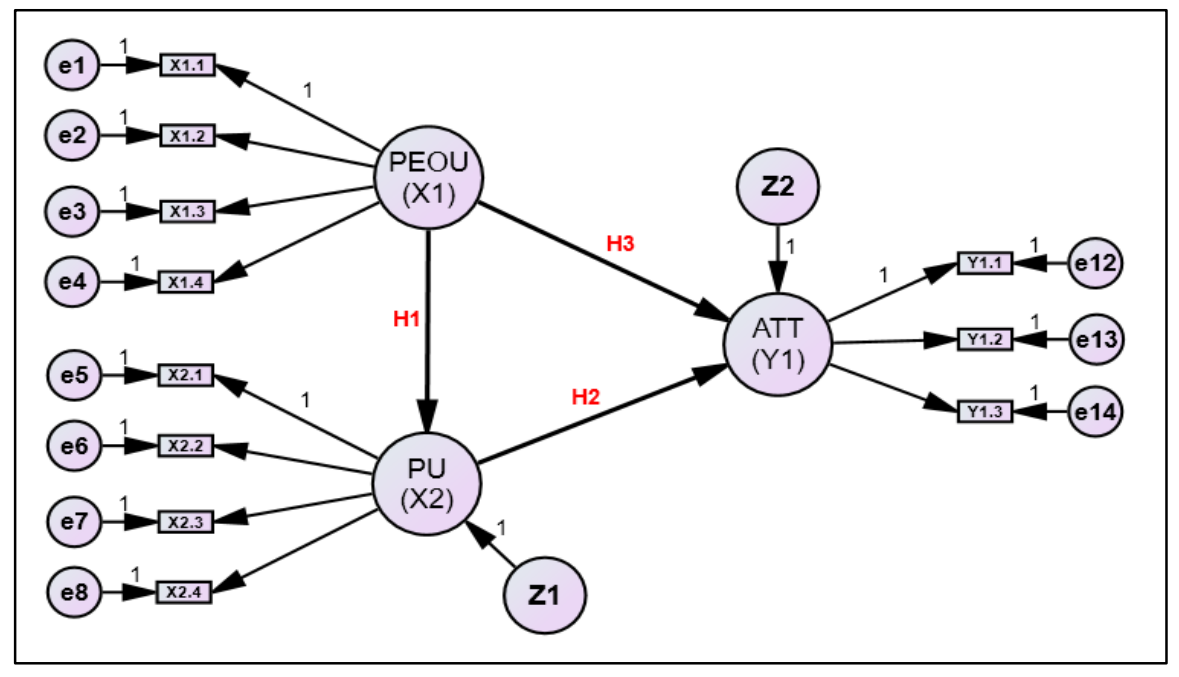

Figure 2.

Flowchart of Causality Relationships

\section{Data Normality Evaluation Testing}

The next testing is to see the level of normality of the data used in this study. This testing is to observe the value of skewness data used, if the value of c.r in skewness data is in the range between +2.58 at a significance level of 0.01 . The results of normality data testing are shown in Table 4.

Table 4.

Testing of Data Normality

\begin{tabular}{ccccc}
\hline Variable & Skew & c.r. & Kurtosis & c.r. \\
\hline X1.1 &, 187 & 1,251 &,- 638 & $-2,137$ \\
X1.2 &,- 069 &,- 461 &,- 389 & $-1,302$ \\
X1.3 &, 150 & 1,06 &,- 655 & $-2,192$ \\
X1.4 &,- 104 &,- 698 &,- 627 & $-2,099$ \\
X2.1 &, 000 &, 001 &, 022 &, 075 \\
X2.1 &, 054 &, 361 &,- 346 & $-1,157$ \\
X2.2 &, 022 &, 148 &,- 307 & $-1,027$ \\
X2.3 &, 170 & 1,140 &,- 270 &,- 905 \\
X2.4 &, 007 &, 044 &, 020 &, 068 \\
Y1.1 &, 089 &, 598 &, 018 &, 061 \\
Y1.2 &, 035 &, 232 &, 681 & 2,281 \\
Y1.3 &, 187 & 1,251 &,- 638 & $-2,137$ \\
& Multivariate & & $\mathbf{5 , 2 2 1}$ & $\mathbf{2 , 5 3 2}$ \\
\hline
\end{tabular}

Source: Data processed, 2019

From the results of data processing shown in Table 4, it can be seen that there is no value of c.r for skewness that is outside the +2.58 range. Thus, the research data used has fulfilled the 
data normality requirements, or it can be said that the research data has been normally distributed.

\section{Structural Equation Modelling (SEM) Analysis}

This analysis is used to determine the structural relationship among the variables studied. Structural relationships occurring among variables can be tested for compatibility with the goodness of fit index. The results of SEM analysis in this study can be seen in Figure 3 below:

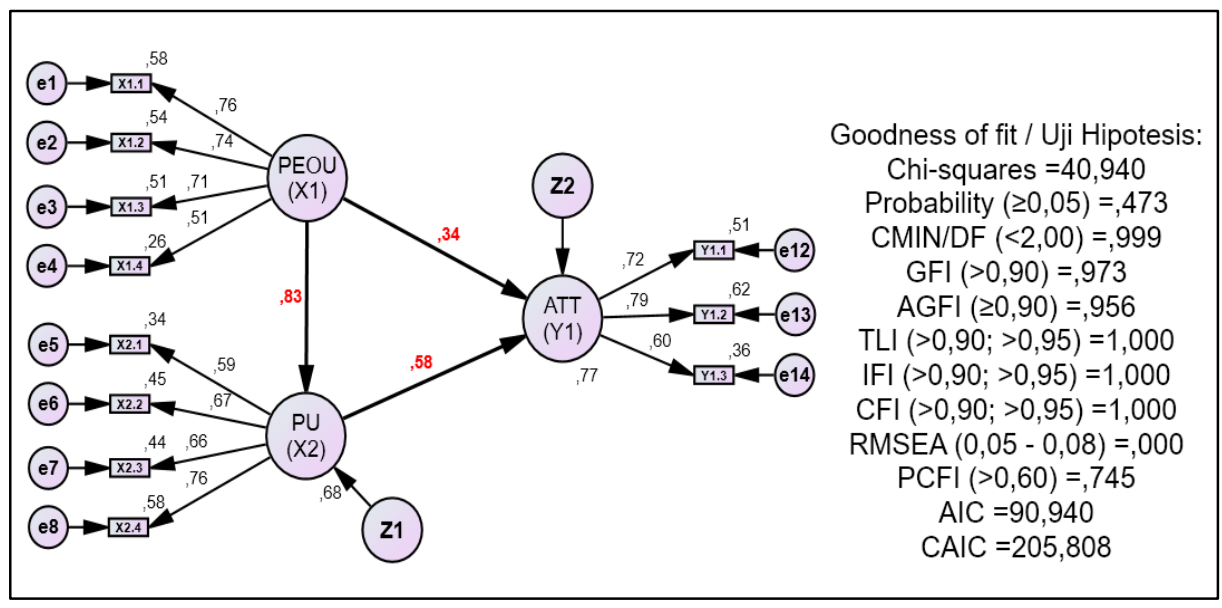

Figure 3.

Measurement of Results of Full CFA Model Test

To find out whether the measurement model has a match with the data can be seen in Table 5 evaluation of Goodness of Fit Indices.

Table 5 .

Computational Results of Goodness of Fit Indices

\begin{tabular}{cccc}
\hline Criteria & Cut Of Value & $\begin{array}{c}\text { Model Test } \\
\text { Results }\end{array}$ & $\begin{array}{c}\text { Model } \\
\text { Evaluation }\end{array}$ \\
\hline Chi-Square & Expected low & 40,940 & Good \\
Probability & $\geq 0,05$ & 0,473 & Good \\
CMIN $\backslash D F$ & $<2,00$ & 0,999 & Good \\
RMSEA & $0,05-0,08$ & 0,000 & Good \\
GFI & $>0,90$ & 0,973 & Good \\
TLI & $>0,90 ;>0,95$ & 1,000 & Good \\
AGFI & $\geq 0,90$ & 0,956 & Good \\
CFI & $>0,90 ;>0,95$ & 1,000 & Good \\
\hline
\end{tabular}

Source: Data processed, 2019

According to Table 5 above, it can be seen that the result of chi square is 40.940 with a probability of $0.473>0.05$, value of RMSEA as many as $0,000<0.08$, value of GFlas many as 0.973>0.90, value of AGFlas many as 0.956>0.90, value of CMIN/DF as many as $0.999<2.00$, 


\section{Tri Rahmat}

value of TLI as many as $1,000>0.95$, and value of CFI as many as $1,000>0.95$ showing that the model suitability test can be well received or fit, thus all observatory variables are declared eligible to be used in further testing.

Test to determine the variables that can be used as a construct or observatory of the latent variable contract can be observed from the estimated coefficient $(\lambda)$ or loading factor, each indicator with the provisions of the value of c.r which in other terms is called $T_{\text {count }} \geq$ 2,000 which can be seen in table 6 as follows:

Table 6.

Loading Factor $(\lambda)$ and Critical Ratio (CR)

\begin{tabular}{|c|c|c|c|c|c|c|}
\hline \multicolumn{3}{|c|}{ Indicator } & \multirow{2}{*}{$\begin{array}{l}\text { Loading } \\
\text { Factor }(\lambda) \\
0,760\end{array}$} & \multirow[t]{2}{*}{$\begin{array}{l}\text { CR/ } \\
\text { Thitung }\end{array}$} & \multirow{2}{*}{$\begin{array}{l}\text { Probability (P) } \\
0.000\end{array}$} & \multirow{2}{*}{$\begin{array}{l}\text { Deception } \\
\text { Sig. }\end{array}$} \\
\hline$X 1.1$ & $<---$ & $\mathrm{X} 1$ & & & & \\
\hline$X 1.2$ & $<---$ & $X_{1}$ & 0,735 & 11,541 & 0.000 & Sig. \\
\hline$\times 1.3$ & $<---$ & $X_{1}$ & 0,715 & 10,897 & 0.000 & Sig. \\
\hline$\times 1.4$ & $<---$ & $X_{1}$ & 0,513 & 7,741 & 0.000 & Sig. \\
\hline X2.1 & $<---$ & $x 2$ & 0,586 & & 0.000 & Sig. \\
\hline$X 2.2$ & $<---$ & $x 2$ & 0,672 & 8,258 & 0.000 & Sig. \\
\hline$X 2.3$ & $<---$ & $x 2$ & 0,661 & 8,320 & 0.000 & Sig. \\
\hline$\times 2.4$ & $<---$ & $x 2$ & 0,761 & 9,000 & 0.000 & Sig. \\
\hline Y1.1 & $<---$ & Y & 0,716 & & 0.000 & Sig. \\
\hline Y1.2 & $<---$ & Y & 0,791 & 11,238 & 0.000 & Sig. \\
\hline Y1.3 & $<---$ & Y & 0,600 & 8,782 & 0.000 & Sig. \\
\hline
\end{tabular}

Source: Data processed, 2019

Based on Table 6, it shows that 11 indicators in which the loading factor meets the requirements $(L F \geq 0,5)$. It illustrates that the 11 indicators mentioned above can describe latent variables well, or they have a contribution to latent variables.

From the loading factor produced above, it can be used to measure the construct validity in which a questionnaire is said to be valid if the questions on the questionnaire are able to reveal something that is measured by the questionnaire. According to Hair et al. (2010: 777) the minimum number of loading factors is $\geq 0.5$ or ideally $\geq 0.7$. Thus, it can be concluded that all questions used to measure the variables of ease, usefulness and comfort, as well as attitude and satisfaction are declared valid. Likewise, the significance level $a=5 \%$ indicates that the probability value of each dimension is smaller than 0.05 . In this study, it indicates that the indicators used toward exogenous and endogenous variables significantly are the dimensions of the factors formed. 


\section{Hypothesis Testing}

After all assumptions can be fulfilled, the hypothesis testing will then be carried out as proposed in the previous chapter. Testing of 3 hypotheses in this study were carried out based on the Critical Ratio (CR) value of a causality relationship from the results of SEM processing as in Table 7 below.

Table 7.

Hypothesis Testing

\begin{tabular}{lllllll}
\hline & & & $\begin{array}{l}\text { Regression } \\
\text { Weight }\end{array}$ & $\begin{array}{l}\text { Critical } \\
\text { Ratio }\end{array}$ & Probability (P) & Deception \\
\hline$X 2$ & $<---$ & $X 1$ & 0,826 & 7,889 & 0.000 & Sig. \\
$Y$ & $<---$ & $X 1$ & 0,335 & 2,343 & 0.019 & Sig. \\
$Y$ & $<---$ & $X 2$ & 0,582 & 3,700 & 0.000 & Sig. \\
\hline
\end{tabular}

Source: Data processed, 2019

Based on Table 7 above, showing the value of regression weight (regression coefficient) of each relationship (effect) variable shows a positive value. It shows that all relationships (variables) provide a direct relationship. Of the three relationships (effect), these variables have an effect. It is indicated by the level of significance $a=5 \%$ used in this study in which if the probability is smaller or equal to 0.05 , it is declared as significant, whereas, if the probability value is greater than 0.05 , it is declared as insignificant.

The first hypothesis stating that the ease of use of the system affecting the usefulness or benefits of the use of the system is accepted. These results are proven in Table 7 showing that the critical ratio value of the ease of use system is 7.889 which is above the critical value of 1.960 at a significance level of 0.05 ( $p$-value $0,000<0.05$ ). Because the value of $c . r$ is greater than 1.960 at a significant level $a=0.05$, meaning that the effect of ease of use of the system is significant to the usefulness or benefits of using the system.

The second hypothesis stating that the ease of use of the system affecting the attitude of the use of the system is accepted. These results are proven in Table 7 showing that the critical ratio value of the ease of use system is 2,343 which is above the critical value of 1,960 at a significance level of 0.05 ( $p$-value $0.019<0.05$ ). It is because the value of $c . r$ is greater than 1.960 at a significant level $a=0.05$, meaning that the effect of ease of use of the system is significant on the usage attitude.

The third hypothesis stating that perceived usefulness or benefits affecting the attitude of use is accepted. These results are proven by the value of the critical ratio of the variable usability or benefits of using the system is 3.700 which is above the critical value of 1.960 at a significance level of 0.05 ( $p$-value $0,000<0.05$ ). It is because of value c.r is greater than 1.960 


\section{Tri Rahmat}

at a significant level $a=0.05$, meaning that the effect of the use or benefits of the use of the system is significant on the attitude of the system use.

Of the three variables having significant positive effect, it shows that the variable of ease of use of the system provides the greatest relationship to the variable of use of the system. This is showed with a regression coefficient of 0.826 , while the relationship between the variable of use of the system and the variable of attitude of the use of the system with a regression coefficient is 0.582 , and the lowest regression coefficient on the relationship of the variable of ease of use of the system and the variable of the attitude of the use of the system is 0.335 .

\section{Effect of Ease of Use Variables on Usefulness Variables (First Hypothesis/H1)}

Based on the results of hypothesis testing obtained and described previously, it stated that ease of use of the system has a positive and significant effect on the usefulness or benefits of use the system. The results are in line with the approach of TAM theory stating that the variable usefulness or benefits of the use of the system is affected by the variable ease of use of the system. The results of this study are in line with the results of previous research conducted by Budi Santoso (2010) stating that ease of use of the system is significant to the usefulness or benefits of use the system.

This study is strengthened by statistical data based on the loading factor of the variable of ease of use of the system in Table 6 in the statement "The composition of the online KRS menu displayed can be understood by students" showing as many as 0.760 , and the usefulness or benefit variable in the statement "overall, the use of online KRS is very useful or beneficial" showing as many as 0.761 . Both statements have a high contribution to the loading factor. It can be interpreted by respondents' opinion that STIE Panca Bhakti Palu has implemented online KRS with a menu that is easily to be understood by students when registering a course.

Meanwhile, the lowest loading factor for the ease of use of the system variable in the statement "If there are changes in facilities or features of online KRS, students can adjust" showing as many as 0.513 , and for the variable of usefulness or benefits of the use of the system in the statement "KRS online is integrated with academic payments" showing as many as 0.586 . It can be interpreted that the interrelationship between the two statements indicates that some respondents were in doubt $(48.3 \%)$ when there was a change in facilities or features in online KRS that could adapt well due to the lack of socialization of the use of online KRS to students, and students felt that the implementation of online KRS needed to be integrated with Academic payments such as confirmation that payment has been made through a related bank, thus impacting the students' decision to use online KRS as an appropriate choice when registering a course. However, with the highest loading factor 
statistical value contributing to the use of the online KRS system, it can be concluded that the first Hypothesis $(\mathrm{HI})$ stating that ease of use of the system affecting the usefulness or benefits of using the system is proven significant or acceptable.

\section{Effect of Ease of Use Variables on Attitude Variables (Second Hypothesis/H2)}

Based on the results of the hypothesis testing obtained and described previously, showing that the ease of use of the online KRS system has a positive and significant effect on the attitude of the use of the system. The results are in line with the approach of TAM theory stating that the variable of usefulness or benefits of the use of the system is affected by the variable of ease of use of the system. The results of this study are in line with the results of previous research conducted by Budi Santoso (2010) stating that the ease of use of the system is significant to the attitude of the use of the system.

This study is strengthened by statistical data based on the loading factor of the variable of ease of use of the system in Table 6 in the statement "The composition of the online KRS menu displayed can be understood by students" showing as many as 0.760 , and the usefulness or benefit variable in the statement "Implementing online KRS is a good idea" showing as many as 0.761 . Both statements have a high contribution to the loading factor. It can be interpreted by respondents' opinion that STIE Panca Bhakti Palu has implemented online KRS with a menu that is easily to be understood by students when registering a course.

Meanwhile, the lowest loading factor for the ease of use of the system variable in the statement "If there are changes in facilities or features of online KRS, students can adjust" showing as many as 0.513 , and for the variable of attitude of the use of the system in the statement "Using online KRS, is the right decision" showing as many as 0.600 . It can be interpreted that the interrelationship between the two statements indicates that therespondents decision using the system were in right choice (48.3\%) when there was a change in facilities or features in online KRS that could adapt well due to the lack of socialization of the use of online KRS to students, so affecting the students' decision to use online KRS as the right choice when registering a course. However, with the highest loading factor statistical value contributing to the ease of use of the online KRS system, so it can be concluded that the second hypothesis $(\mathrm{H} 2)$ which states that ease of use of the system has an effect on the attitude of using the system proved significant or acceptable.

\section{The Effect of Usefulness Variables on Attitude Variables (Third Hypothesis/H3)}

Based on the results of the hypothesis testing obtained and previously described, showing that the usefulness or benefits of the use of the online KRS system has a positive and significant effect on the attitude of the use of the system. 


\section{Tri Rahmat}

The results of the study are in line with the approach of TAM theory stating that the variable of attitude of the use of the system is affected by the variable of usefulness or benefits of the use of the system. The results of this study are in line with the results of previous research conducted by Budi Santoso (2010) stating that the usefulness or benefits of the use of the system are significant to the attitude of the use of the system.

The above interpretation is strengthened by statistical data based on the loading factor of the usefulness or benefit variable in Table 6 in the statement "Overall, the use of online KRS is very useful or has a benefit" showing as many as 0.761 , and the variable of attitude of the use of the system in the statement "implementing online KRS is a good idea" showing as many as 0.791. Both statements have a high contribution to the loading factor. It can be interpreted by respondents' opinion that, so far, the implementation of online KRS is useful or has a benefit in helping online KRS registration.

Meanwhile, the lowest loading factor for the variable of perceived usefulness or benefits in the statement "KRS online is integrated with Academic payment" showing as many as 0.586 , and for the variable of attitude of the use of the system in the statement "Using KRS online is the right decision" showing as many as 0.600 . It can be interpreted that the interrelationship between the two statements indicates that the decision of respondents to use the system is the right decision. Online KRS also has not implemented the availability of online payment features. However, with the highest loading factor statistical value contributing to the usefulness or benefits of the use of the online KRS system, so that it can be concluded that the third hypothesis $(\mathrm{H} 3)$ stating that the usefulness or benefit of the use of the system affecting the attitude of the use of the system are proved significant or acceptable.

\section{CONCLUSIONS}

The ease of use of the system has a positive and significant effect on the usefulness or benefits of the use of the system. The ease of use of the system has a positive and significant effect on the attitude of the use of the system. The usefulness or benefit of the use of the system has a positive and significant effect on the attitude of the use of the system.

If there is a change in facilities and system functions that are still lacking or even have not been used maximally by the user, it is better for college to periodically socialize information to students as system users and provide training modules for the use of the online KRS system. The university is also expected to provide proper facilities in the Online KRS system that is integrated with partner banks for tuition fee online payment. Hence, the university will obtain a great benefit from faster payment process made by students.To increase users of information technology availability, improvements must be made related to slow networks 
and hotspot areas. The availability of helpdesk support has also become important in the implementation of academic information systems. Therefore, it is recommended to provide helpdesk support that can be contacted online either via chat or telephone so that the response of user complaints can be served more quickly.

Future research should increase the variables and indicators, and it can test the influence of other variables that can be included in the TAM method so that the results of subsequent studies can be assessed from a broader perspective so that it later can help in improving and increasing system performance that will be used by students (users). For future research, in primary data collection, it is not only by questionnaire but also by field observations, as well as direct interviews with respondents so that the results of the analysis obtained are comprehensive.

\section{REFERENCES}

Darmawan, D. 2012. Pendidikan Teknologi Informasi dan Komunikasi. Bandung: PT Remaja Rosdakarya.

Hair, J. F., Black. W. C., Babin. B. J., and Anderson. R. E. 2010. Multivariate Data Analysis, Seventh Edition. Pearson Prentice Hall, New Jersey.

Jogiyanto. 2008. Sistem Informasi Keperilakuan. Edisi Revisi Yogyakarta: Andi Offset.

Jogiyanto, H. M. 2008. Metodologi Penelitian Sistem Informasi: Pedoman dan Contoh Melakukan Penelitian di Bidang Sistem Teknologi Informasi. Yogyakarta: Andi Offset.

Nazir, M. 2011. Metode Penelitian. Jakarta: Ghalia Indonesia.

Noor, J. 2011 . Metodologi Penelitian. Jakarta: Prenada Media Group.

Sugiyono. 2016. Metode Penelitian Pendidikan (Pendekatan Kuantitatif, Kualitatif dan R \& amp, D. Bandung: Alfabeta.

Sutabri, T. 2014. Pengantar Teknologi Informasi". Edisi Pertama. Andi, Yogyakarta.

Sutarman. 2009. Pengantar teknologi Informasi. Bumi Aksara, Jakarta.

Adhiputra, M. W. 2015. Aplikasi Technology Acceptance Model terhadap Pengguna Layanan Internet Banking. Jurnal Bisnis dan Komunikasi. 2 (1): 52-63. Available at: http://digilib.mercubuana.ac.id.

Ajzen, I., and Fishbein, M. 1975. Belief, Attitude, Intention, and Behavior: An Introduction to Theory and Research. 129-385, Addison-Wesley, Reading, MA. Available at: https://philarchive.org.

Adams, D. A., Nelson, R. R., Todd, P. A. 1992. Perceived usefulness, ease of use, and usage of information technology: areplication. MIS Quarterly. 16 (2): 227-247. Available at: DOI: $<10.2307 / 249577>$ 


\section{Tri Rahmat}

Budi, S. 2010. Pengaruh Perceived Usefulness, Perceived Ease of Use, dan Perceived Enjoymet Terhadap Penerimaan Teknologi Informasi. Jurnal Akuntansi dan Bisnis Universitas Sebelas Maret. 10 (2). Available at : <DOI: 10.20961/jab.v10i2.112>

Fred, D., Davis, R. P., Bagozzi, P. R., and Warshaw. 1989. User Acceptance of Computer Technolog: A Comparisson of Two Therical Models. Journal of management Science. 35(8): 982-1003. Available at : <https://www.jstor.org>

Hendra, J., and Iskandar, A. 2016. AplikasI Model TAM terhadap Penggunaan Layanan Internet Banking di Kantor Bank Jatim Cabang Situbondo. Ecobuss, 4 (1): 1-9. Available at : <https://ejournal.upm.ac.id>

Igbaria, M. 1990. End User Computing Effectiveness: A Structural Equation Model. Omega. 637-652.

Istiarni, P. R., and Hadiprajitno, P. B., (2014). Analisis Pengaruh Persepsi Manfaat, Kemudahan Penggunaan dan Kredibilitas terhadap Minat Pengguna Berulang Internet Banking dengan Sikap Pengguna sebagai Variabel Intervening. Diponegoro Journal of Accounting. 3 (2): 1-10. Available at : <https://ejournal3.undip.ac.id>

Portner, C. E., and Naveen, D. 2006. "Using The Technology Acceptance Model to Explain How Attitudes Determine Internet Usage: The Role of Perceived Access, Barriers and Demographics." Journal of Business Research. 59(9): 999-1007. Available at: <DOI: 10.1016/j.jbusres.2006.06.003>

Rahadi, D. R., and Zainal. 2015. Analisis Technology Acceptance Model pada Industri Perbankan. Jurnal Sistem Informasi. 7(2): 837-851. Available at: https://ejournal.unsri.ac.id

Rangkuti, F. 2013. Riset Pemasaran. Gramedia Pustaka Utama: Jakarta.

Setiadi, J. N. 2003. Perilaku Konsumen: Konsep dan Implikasi untuk Strategi dan Penelitian Pemasaran. Jakarta: Prenada Media.

Venkatesh, V, and Davis, F. D. 1996. A Model of The Antecendents of Perceived Ease of Use: Develompment dan Test. Decision Science. 27 (3): 451-481. Available at : <https://onlinelibrary.wiley.com>

Yasa, N. N., Ratnaningrum, L. P., and Sukaatmaja, P. G. 2014. The Aplication of Technology Acceptance Model on Internet Banking Users in the City of Denpasar. Manajemen dan Kewirausahaan. 16 (2): 93-102.Available at : <DOI: 10.9744/jmk.16.2.93-102> 